NBER WORKING PAPER SERIES

\title{
RESTRICTION OF INTERNATIONAL PRODUCTION: \\ THE EFFECTS ON THE DOMESTIC ECONOMY
}

David G. Hartman

Working Paper No. 307

NATIONAL BUREAU OF ECONOMIC RESEARCH 1050 Massachusetts Avenue

Cambridge MA 02138

December 1978

A previous draft of this paper was presented at the 1978 Econometric Society Annual Meeting at Chicago, Illinois. I am greatly indebted to Martin Feldstein for his suggestions. I have also benefited from discussions with Richard Caves, Thomas Horst, Liam Ebrill, Arturo Brillembourg, and Jevon Lee. The research reported here is part of the NBER's Special Research Project on Capital Formation and is related to the NBER's Programs in International Studies and Business Taxation and Finance. Any views expressed are those of the author and not those of the NBER. 
Summary

RESTRICTION OF INTERNATIONAL PRODUCTION:

THE EFFECTS ON THE DOMESTIC ECONOMY

by

Dav1d G. llartman

This paper examines the argument that restricting domestic firms' production abroad by, for example, imposing a tax on foreign source income, can increase domestic welfare and alter the income distribution to favor labor. These arguments follow directly from a characterization of the international producer as a facilitator of capital flows. The available evidence suggests, however, that U.S. multinational firms have a much broader role than transferring abundant U.S. capital abroad. In this paper the firm is viewed as able to compete abroad for a variety of reasons, including an ability to make use of technological and other cost advantages over local producers. Then, the effect of its operations abroad on the domestic capital stock is no longer so obvious. It is argued that at most a part of the marginal capital employed abroad is obtained at the expense of the capital stock of the domestic economy. The paper then presents a simple model which indicates that domestic labor can either gain or lose relative to capital, and home country welfare can either increase or decline, as a result of restricting the foreign operations of domestic firms. The results depend on the ultimate source of the capital placed abroad, the relative factor intensity of production by the multinational firm, and whether the multinational firm produces the home country's importable or exportable good. Since none of the cases considered seems totally implausible, the case for reducing international production cannot be made on the traditional grounds without further empirical evidence.

David G. Hartman National Bureau of Economic Research Harvard University

(617) $868-3925$ 


\section{Introduction}

For a number of years, a minority of the United States Congress has been urging adoption of measures to reduce the level of foreign operations of U.S.based firms. The discussions have centered on a more restrictive policy of income taxation, but proposals for more direct restriction of foreign investment have also been advanced. Organized labor has given strong support to such policy changes, arguing that workers are harmed by the employment abroad of U.S. capital and know-how. Their position is bolstered by the long-held theory of economists that national welfare can be improved by the appropriate reduction in foreign investment from its free-market lovel.

Labor's case for restricting the firms' foreign operations is often expressed in terms of a loss in home country jobs. Several studies, which are reviewed in Bergsten, et al (1978), estimate the net effect on employment of U.S. foreign investment. Since the loss of jobs is a temporary adjustment problem and also depends on government macroeconomic policies, these estimates are difficult to interpret. Other authors have, however, pointed to a more permanent impact on labor, the reduction in wages caused by the decline in the home country's capital-1abor ratio which results as capital moves abroad. ${ }^{1}$

There are two distinct strands to the national welfare argument for restricting the foreign production of U.S. firms. ${ }^{2}$ The first depends on the existence of host country taxes on the income earned in the host country by U.S. firms. Profit-maximizing firms, it is argued, will equate marginal returns to capital, net of U.S. and host country taxes, across all countries in which they operate. This implies that under the current system of crediting foreign tax payments against the U.S. income tax liability, the U.S. eams less, by the amount of the foreign tax, on the marginal unit of capital placed abroad than it would if the 
capital were to remain at home. That is, firms transfer too much capital abroad from the standpoint of national welfare; the U.S. would do well to reduce the level of foreign investment. Taking into account only this "foreign tax effect", it would appear that home country welfare could be maximized by allowing a deduction, rather than a credit, for forelgn tax payments. 3

Other writers have pointed to a second source of gain to the home country from restricting foreign investment. They have argued that the home country can increase its earnings on the stock of capital employed abroad by insuring that a higher, not equal, return is earned at the margin on capital placed abroad. Achieving this monopoly gain requires government intervention, of course, only if the home country firms themselves do not act as a monopoly supplier of capital (cf.Jasay (1960)). In other cases even a home country system of "taxation with deduction of foreign taxes" is apparently insufficiently restrictive from the standpoint of home country welfare. Thurow (1976) uses this argument as a basis for estimating the gain available to the U.S. from "optimal taxation" of the income earned abroad by U.S. firms.

The grounds on which government restriction of firm's foreign investment has been proposed are, then, that such a restriction is thought to alter the home country's income distribution in favor of labor and to improve home country welfare in general. Both arguments, as just described, rely crucially on a characterization of the multinational firm as a transferor of domestic capital abroad. 4 It seems curious that this view of the firms has persisted in discussions of optimal policy, as accumulating evidence seems to contradict the notion that capital transfers play a major role. 
Critics of the hypothesis that foreign investors operate primarily to facilitate capital flows include Hymer (1960), Vernon (1966), Gruber, et al (1967), Caves (1971), and Horst (1972). This criticism is supported by recent evidence. The rapidly growing flows of portfollo capital and direct investment into the U.S. argues against the view that U.S. firms are investing abroad primarily to take advantage of an abundance of capital at home. Also, a substantial fraction of the capttal employed abroad by U.S. firms is obtained outside the U.S.

The effects of government restrictions on the foreign operations of firms have previously been studied using an overly simplistic characterization of the multinational firm. This paper takes a broader view of the nature of the firm's foreign operations, allowing for a variety of factors, including technological and managerial advantages over local producers, which may explain the firm's competitiveness abroad. The policy conclusions which result differ substantially from those of the traditional analysis. Specifically, both the usual national welfare and distribution arguments for restricting production abroad are shown to hold only in particular cases.

The impact of restrictive government policies on the domestic capital stock is a highly important factor in our analysis. Having rojected the traditional approach to determining the effect of foreign investment on the domestic capital stock, it is necessary to formulate an alternative. So, before considering the policy issues, we address the question of whether the domestic capital stock is affected by international production decision. 
II. The Impact of Forelgn Investment on the International Distribution of Capital In examining this crucial 1ssue of the source of capital employed abroad by multinational firms, it is only the ultimate source in the aggregate that is of interest. For that reason, the individual firm's decision on how to finance its investment is not of concern here. Furthermore, even the observed aggregate financial behavior of multinational firms may not have relevance in this context.

For example, if there were compensating long-term portfolio capital flows which were perfectly interest-elastic, the worldwide distribution of real capital would be unaffected by the financial declsions of firms; even in the aggregate. In this case of perfectly elastic capital flows, the issues of policies towards capital movements and the remainder of a multinational firm's operations would be separable. Since the effects on the home economy of restricting capital flows have been examined in detail, ${ }^{5}$ only the impacts of a change in the level of foreign production would remain to be explored. While we will consider, as a special case, the restriction of international production when no change in the capital stock takes place, there are a number of reasons for believing that the operations of multinational firms do affect the distribution of capital across nations. That is, the international character of total assets held by the home country is altered as the level of international production changes.

One factor of importance is the ability of multinational firms to overcome barriers to capital mobility. The existence of barriers to portfolio capital flows has been described as providing an additional advantage to the multinational firm. The multinational firm is favored because of its ability to transfer funds internally without being required to engage in market transactions. This ability is particularly advantageous if local capital markets are inefficient or nonexistent or if government interference with capital transactions is pervasive. 
Clearly, if multinational firms perform this arbitrage function to any significant extent, their operations' impact on the capital stocks of the nations in which they operate cannot be ignored. Discussions of the ability of multinational firms to facilitate capltal flows can be found in Agmon and Lessard (1977) and Rugman (1977) .

A second factor tending to result in the domestic capital stock and the level of international production not being separable issues is uncertainty. Not wanting to be dependent upon any assumption that risk is a matter of concern to individual firms, we will look through the corporation to the desire of individuals who own shares in the firm's returns to minimize the riskiness of their portfolios. A convenient way of attacking the issue of capital transfer is to question whether firm owners, when faced with an increased incentive to employ capital abroad (in order to increase production), would increase net borrowing abroad in equal amount to the capltal requirement of the production increase. ${ }^{6}$ The answer, in general, is that a portion of the required capital is obtained at the expense of the home country's capital stock.

Borrowing in the host country requires that the capital return be paid in the local currency. Individuals are concerned about the correlation of real returns to assets with real costs of holding liabilities in their portfolios. So, the attractiveness of increased local borrowing by U.S. investors depends on the relationship between unexpected changes in the dollar return to capital employed abroad and unanticipated changes in the exchange rate. The incentive to obtain a marginal unit of capital locally is smaller the more likely are unanticipated exchange rate changes to reflect fluctuations in input and output prices faced by the multinational firm in the host country. Since the available evidence 
points to relative prices betng affected by exchange rate changes, except over a very long pertod (Dornbusch and Krugman (1976) and Krugman (1978)), there is a clear reason for firms to obtain capital locally. On the other hand, the possibility of an unantictpated inflation at home being reflected in exchange rates makes capital transfer relattvely less risky. Further complicating decisions is the possibtlity of government interference in exchange markets.

To the extent that U.S. multinational firms are superior vehicles for international portfolio transactions, the capital transfer from the U.S. which accompanies aggregate investment overseas may be indicative of the overall effect. It has been observed that abouthalf of the capttal from sources external to foreign afflliates of U.S. firms is obtained outside the U.S. at the margin. ${ }^{7}$ This fraction appears to have been relatively stable, except for periods of government intervention. So, both the traditional view that the home country's capital stock declines by the amount of the capital required for an increase in home country firms' production abroad and the other extreme of no capital transfer seem to be contradicted in the U.S. case.

It seems safe to assume that investors would not desire that multinational production be carried out using entirely host country capital at the margin. Investors in the rest of the world will, similarly, be conscious of risk when making long-term portfolio capital tnvestments. Therefore, government restrictions on multinational firms will tend to cause an increase in the home capital stock which portfolio capital flows will not entirely eliminate. If portfolio capital flows were perfectly interest-elastic, the national welfare and distribution questions which motivated this paper would be uninteresting. 
III. The Effects on the Domestic Economy of Reducing the Level of Production by Domestic Firms Abroad

From the discussion of the previous section, it seems appropriate to take new look the effects of pollcies toward multinational corporations. Since our theory suggests that the home economy does not necessarily supply one hundred percent of the capital used in production abroad, the traditional policy model is not applicable. We will now explore the implications of the relationship between capital and international production.

This model will follow the tradition of assuming that there are only two countries and two traded goods produced with capital and labor available in fixed supply. Since the results are to be regarded as only illustrative of possible solutions, free trade without transportation costs is also assumed to prevail. This assumption precludes, of course, any analys is of simultaneous restriction of intemational production and imposition of tariffs. ${ }^{8}$ The multinational firm is viewed as producing one of the goods $(X)$ abroad because of its advantages over local producers. A policy measure is introduced which causes production abroad by the home country's firms to decline, with a corresponding decline in capital used in that production, according to the relationship given by (1).

$$
d x^{*}=\frac{d k_{x}^{*}}{a_{k x}^{\star}}-x^{*} \frac{d a_{k x}^{\star}}{a_{k x}^{\star}}
$$

The host country is indicated by $a^{\prime \prime * " ~ a n d ~} a_{k x}^{*}$ is the capital required for producing a unit of $X^{*}$. Equation (1) allows for the possibility that the restrictive policy causes a change in the real wage in the host country and, hence, in $a_{k x}^{*}$. 
The increase in the home country capital stock which results from the production decline abroad ts, then, given by equation (2), where $\delta$ is the fraction of the capital previously used to produce $\mathrm{dX}^{*}$ which returns to the home country.

$$
d x=-\delta d K_{x}^{*}
$$

This model is specified assuming that the government simply mandates a reduction in $X^{\star}$. Other policy measures, such as taxing foreign source income at a higher rate, could be analyzed in the same way. However, it is useful to consider a simple reduction in $X^{*}$, as it facilitates examination of two limiting cases of interest. In addition, we assume that the host economy has imposed no taxes or other restrictions on foreign investment. Therefore, the analysis abstracts from the "foreign tax effect" for simpliclty. It causes no confusion, however, to think of any policy prescriptions following from this discussion as deviations from the basic "taxation with deduction for forelgn tax payments" policy.

With domestic prices and factor costs held fixed, the injection of capital into the domestic economy would change production of good $X$ as indicated by (3).

$$
d x=\frac{-\delta d k_{x}^{\star}}{\left(a_{k x}-\frac{a_{k y} a_{1 x}}{a_{1 y}}\right)}
$$

Equation (3) follows from the necessity that all of the additional capital be absorbed by the production of $\mathrm{X}$ or $\mathrm{Y}$, at initial relative factor costs. Therefore, the total effect on world production of good $x$, at initial prices, would be given by equation (4).

$$
\left(d x^{*}+d x\right)=\left(\frac{1}{a_{k x}^{*}}-\frac{\delta}{\left(a_{k x}-\frac{a_{k y} a_{1 x}}{a_{1 y}}\right)}\right) d k_{x}^{*}-x^{*} \frac{d a_{k x}^{*}}{a_{k x}^{*}}
$$


The impacts on the domestic economy as prices and factor rewards are allowed to vary are now usefully explored by considering two polar cases. First, the analysis is done assuming that all capital formerly used abroad returns to the domestic economy, and then repeated under the assumption that none of the capital was used abroad at the expense of the home economy at the margin.

\section{A. Full Capttal Transfer In this case, government-induced reduction} in the production abroad of good $X$ is accompanied by an increase in the home country's capital stock by the full amount previously used to produce good $X$ abroad (that is, $\delta=1$ ). To determine the effects on prices of the government's policy, we first examine the fixed-price change in production of good $x$.

At the initial relative prices, a capital inflow will increase home country production of $X$ if $X$ is the home country's capital-intensive good, and it will decrease if $X$ is relatively labor intensive. With labor assumed immobile across national borders, the Rybcyzynski theorem dicates that production of good $Y$ changes in the opposite direction.

In determining the effect of the policy on worldwide production of $X$ given by (4), the sign of the final term must first be determined. Since the host country labor which formerly produced $\mathrm{dX}$ * must be absorbed by the host economy without any change in the stock of capital available for producing the host country good $Y$, the wage rate in the host country must decline. Therefore, the last term in (4) is positive.

It is, then, clear that if multinational firms produce the good which is capital intensive in production in the home country and if the firms do not use sufficiently less capital-intensive methods abroad, the government's action results in an increase in the total world production of good $x$. The relative price of $\mathrm{X}$ must, then decline. By the Stolper-Samue1son theorem, 
the price decline for $X$ leads to a rise in the wage and a decline in capital's return in line with the traditional conclusion about such a policy.

The exception, just noted, of firms which use significantly less, capital-intensive methods abroad may or may not be of practical importance. But, since it results from the most traditional case of full capital transfer, even the theoretical possibility is surprising.

Conversely, if good $\mathrm{X}$ is the labor-intensive good in the home economy, its worldwide production declines in response to a capital repatriation, as both production at home and abroad decline (at fixed prices). As a result, the price of good $X$ must rise, leading to an increase in the home country's wage-rental ratio.

So, labor will not usually lose relative to capital as a result of government restriction of international production when all capital used abroad is obtained at the expense of the home economy. Only if the factor proportion used in domestic production of good $X$ differs appreciably from that used abroad, can a counter-intuitive result be obtained.

With respect to national welfare, it is useful to consider two effects which, while clearly related, will be discussed separately. The first factor to be considered is the change in the real return to the existing stock of home country capital abroad. As pointed out above, the wage in the host country declines unambiguously as a result of a restriction on foreign investment. So, the return to capital used by producers of $X^{*}$ increases. Therefore, beginning from a situation of no restrictions on international production, the imposition of some such restrictive policy tends to increase U.S. national welfare by raising the return to the stock of capital held abroad. 
The change in the home country's terms of trade could obviously affect domestic welfare in either direction depending on the sign of the relative price change and on which good is the home country's exportable. So, oven in the case of full capital transfer when production of a good abroad is coupled with the transfer, the implications for national welfare become ambiguous. 9

B. No Capital Transfer When no capital employed abroad is obtained at the expense of the home country capltal stock, the cases normally made for restricting international production aro oven less cloar. Such a governmentel policy move causes a reduction in the production of $X^{*}$ abroad, without any corresponding change in the domestic capital stock. The only effects on the home country arise, then, because of the relative increase in the price of $x$. The resulting (Stolper-Samuelson) effect on the home country's wage-rental ratto is given by the familiar equation (5).

$$
(\hat{w}-\hat{r})=\frac{1}{|\theta|} \hat{p}
$$

$P$ is the relative price of $\operatorname{good} X$, and $|\theta|$ is the determinant of the matrix having representative element, $\theta_{i j}$, the share of the price of good $j$ which represents a payment to factor $i$. The sign of $|\theta|$ is determined by the relative factor intensities in the home country. If the good produced Internationally is capital intensive in the home economy, home country labor will lose when international production is restricted. On the other hand, restricting production abroad of a good which is labor intensive at home causes the home country's wage-rental ratio to rise. So, 1abor's 
traditional argument for reducing the level of operations of multinational firms does not necessarily hold.

The national welfare argument gives equally ambiguous conclusions. A reduction in host country production $X^{*}$ does not generally free up capital and labor in the correct proportion for production of $Y$ * at existing factor costs. The wage-rental ratio in the host economy rises of $Y^{*}$ is relatively labor intensive, and it falls if $Y^{*}$ is relatively capital intensive. The real return to the intra-marginal capital employed abroad by the home country can, therefore, be changed in either direction by the government's restrictive policy. Since the relative price of $X$ rises, the direction of the terms of trade effect on national welfare depends on whether good $X$ is the importable or exportable good.

C. Partial Capital Transfer As was pointed out in Section II, the case of full capital transfer and of no capital transfer are to be regarded as only limiting cases, with neither likely to have wide applicability. Since examining the two extreme cases produces such a wide range of possible results (see Table 1 ,) we must conclude that a government limitation on U.S. firms' production abroad could affect both factor rewards and U.S. welfare in either direction.

\section{The Need for Further Research}

Clearly, the effects of even a very straight-forward policy change cannot be predicted without a great deal more empirical evidence than is currently available. The relative capital intensity of U.S. firms' production abroad is controversial, with existing studies providing insufficient reason to choose either alternative. Also, while firms often produce abroad as a substitute for exporting, some goods 


\section{TABLE 1}

EFFECTS OF RESTRICTING INTERNATIONAL PRODUCTION (by factor intensity of multinational-produced good)

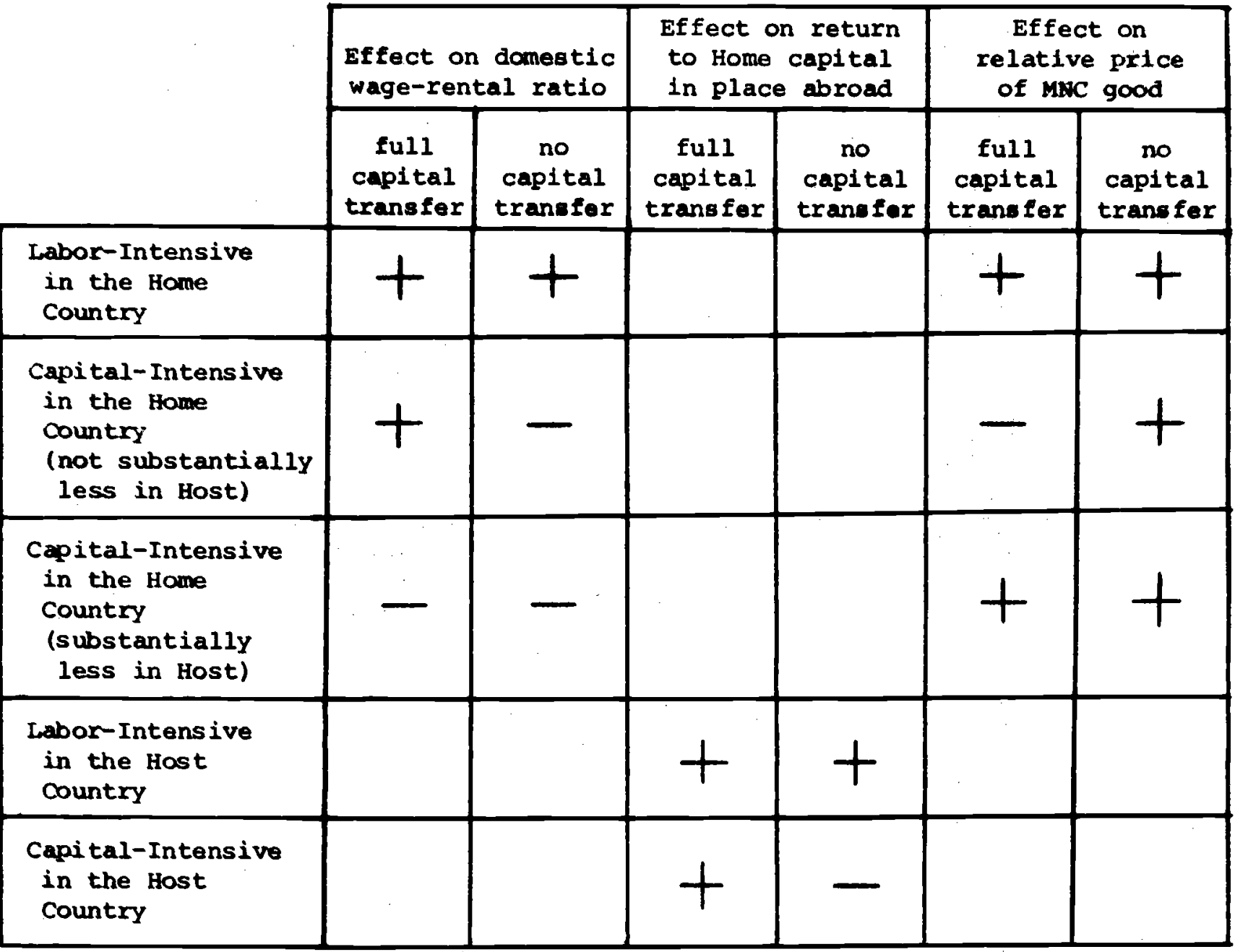


produced by the firms are imported by the U.S., so the direction of the terms of trade effect is uncertain. Finally, although the sources of capital employed by U.S. firms abroad has been studied, this ovidence provides at most a partial answer to the question of effects on the domestic capttal stock.

Furthermore, the very simple analysis presented in this paper, although seemingly more realistic than prevtous discussions of the issue, falls far short of the type of model needed to confidently recommend a particular policy. The analysis, for example, has assumed the inttial position to be one of free trade. Since one of the primary reasons gtven for producting a good abroad is that tariffs impede the good's export, one refinement of the basic model would be to include tariffs. Also, the results hinge critically on the assumption that the host country does not begin production of $X$ as the multinational firms' production declines. One attractive way of including host country production might be to include more goods which, while not precisely the same as the multinational firms' production, are close substitutes. The addition of more traded goods could moderate the results in another way as we11. The existence of multiple goods, to which displaced host country labor may flow, may tend to lessen the impact of reduced $X^{*}$ production on wages. A further extension of the model would allow exploration of the implications of business being truly multinational, i.e., operating in several countries.

As with any comparative static analysis, this paper has ignored the process of adjustment. Since labor's case for restricting international production may be partially based on the adjustment costs imposed on labor as production shifts abroad, the adjustment process may be important in a policy decision. However, any major policy change imposes the same sort of adjustment costs, so the issue is one of comparative costs. 
Any of these extensions would produce a model with highly complex relationships among variables. Use of such a model would probably require empirical evidence to be used for obtaining simulation estimates of policy effects. In any event, the model in this paper must be regarded as 11lustrative.

\section{v. Conclusions}

In a world of foreign exchange risk, some portion of the capital employed abroad by multinational fims will be obtalned locally and some portion will be transferred from the home country. Since portfolio capital flows, by the same argument, are not perfectly elastic, the aggregate distribution of capital across countries is changed as a result of international production, but does not change by the full amount required by the multinational firms' operations abroad. So, factor rewards and home country welfare are affected by policies which alter international production levels, but not necessarily as traditional policy analyses would indicate. This paper has shown, using a simple mode1, that labor can either gain or lose relative to capital and that the home country welfare can either increase or decline as a result of restricting the foreign operations of home country firms. Since none of the examples considered seems totally implausible, the case for reducing multinational activity cannot be made on any of these grounds without further empirical evidence. 


\section{Footnotes}

1. Recent work by P. Musgrave (1975) and Thurow (1976) has provided estimates of the loss to U.S. labor derived from such an analysis.

2. A more complete review of these discussions can be found in Bergsten, et al (1978).

3. This argument is associated with P. Musgrave (1969 and 1975).

4. In addition to the studies just cited, this emphasis on capital flows has dominated studies of optimal host country policy (see, for example, MacDougall (1960) and Corden (1974)).

5. In addition to the work previously cited, which discussed capital flows as the characteristic feature of foreign investment by U.S. firms, see Jones (1967).

6. This includes, of course, the possibility that individuals would cut previous net lending abroad.

7. See Hartman (1978).

8. In a model of portfolio capital flows, Jones (1967) considers taxation of both capital and trade flows.

9. Considering domestic aggregate economic welfare with no concem for the effects of policy on other nations is, of course, limited as a criterion for policy, but may be useful nevertheless in describing the policy impacts. 
$\underline{\text { References }}$

Agmon, T. and D. Lessard, "Investor Recognition of Corporate International Diversification," Journal of Finance, 32 (Sept. 1977), pp. 1049-55.

Bergsten, C. Fred, Thomas Horst, and Theodore H. Moran, American Multinationals and American Interests, Washington, D.C. The Brookings Institution, 1978.

Caves, R.E., "International Corporations: The Industrial Economics of Foreign Investment," Economica, 38 (Februaru 1971), pp. 1-27.

Corden, W.M., Trade Policy and Economic Welfare, Oxford, Clarendon Press, 1974.

Dornbusch, Rudiger, and Paul Krugman, "Flexible Exchange Rates in the Short-Run," Brookings Papers on Economic Activity, (Vol. 3, 1976), pp. 537-584.

Gruber, W., D. Mehta, and R. Vernon, "The $R \& D$ Factor in International Trade and International Investment of U.S. Industries," Journal of Political Economy, 1975 (January-February 1967), pp. 20-37.

Hartman, D.G., "International Capital Flows and the U.S. Economy," National Bureau of Economic Research Working Paper, 1978.

Horst, Thomas, "Firm and Industry Determinants of the Decision to Invest Abroad: An Empirical Study," Review of Economics and Statistics, 54 (August 1972), pp. 258-266.

Hymer, S., The International Operation of National Firms: A Study in Direct Foreign Investment, Ph.D. dissertation, M.I.T., 1960 .

Jasay, A.E., "The Social Choice Between Home and Overseas Investment," Economic Journal, 70 (March 1960), pp. 70-105.

Jones, R.E., "International Capital Movements and the Theory. of Tariffs and Trade," Quarterly Journal of Economics, 81 (February 1967), pp. 1-38.

Krugman, Paul R., "Purchasing Power Parity and Exchange Rates," Journal of International Economics 8 (August 1978), pp. 397-408.

MacDougal1, G.D.A., "The Benefits and Costs of Private Investment From Abroad: A Theoretical Approach," Bullet in of the Oxford University Institute of Statistics, 22 (August 1960), pp. 189-211.

Musgrave, P.B., United States Taxation of Foreign Investment Income: Issues and Arguments, Cambridge, Mass., Harvard Law School International Tax Program, 1969.

, Direct Investment Abroad and the Multinationals: Effects on the United States Economy, Senate Foreign Relations Committee Print, 94th Congress, 1st Session, August 1975.

Rugman, A.M., "Risk, Direct Investment and International Diversification," Weltwirtschaftliches Archiv, Band 113, Heft 3, 1977, pp. 487-500. 
Thurow, L.C., "International Factor Movements and the American Distribution of Income," Intermountain Economic Review, vol. II, no. 1 (Spring 1976), pp. 13-24.

Vernon, Raymond, "International Investment and International Trade in the Product Cycle," Quarterly Journal of Economics, 30 (May 1966), pp. 190-207. 